\title{
Inhibition of Human Erythroid Colony-forming Units by Tumor Necrosis Factor Requires Beta Interferon
}

Robert T. Means, Jr., and Sanford B. Krantz

Hematology Division, Department of Medicine, Department of Veterans Affairs Medical Center

Nashville, Tennessee and Vanderbilt University School of Medicine, Nashville, Tennessee 37232

\begin{abstract}
We have previously reported that inhibition of human CFU-erythroid ( $E$ ) colony formation by tumor necrosis factor (TNF) is an indirect effect mediated by a soluble factor released from a fraction of marrow accessory cells which are predominantly stromal elements (Means, R. T., Jr., E. N. Dessypris, and S. B. Krantz. 1990. J. Clin. Invest. 86:538-541). Further studies reported here identify a mediator of this effect.

The inhibitory effect of recombinant TNF on marrow CFU$E$ is ablated by neutralizing antibodies to human $\beta$ IFN, but not by antibodies to $\gamma$ IFN or IL-1. Anti- $\beta$ IFN also neutralizes the inhibitory effect of conditioned medium prepared from marrow cells exposed to TNF. Human $\beta$ IFN inhibits colony formation by unpurified marrow CFU-E as well as highly purified CFU-E generated from peripheral blood progenitors, and limiting dilution analysis shows that this is a direct inhibitory effect.

TNF has been implicated in the pathogenesis of the anemia of chronic diseases since blood TNF levels are elevated in many patients with this syndrome, and since exposure to TNF produces a similar anemia in either humans or mice. The present study demonstrates that $\beta$ IFN is a required mediator of this inhibitory effect on erythropoiesis. (J. Clin. Invest. 1993. 91:416-419.) Key words: erythropoiesis • anemia of chronic disease • marrow stromal cells $\bullet$ cytokines $\bullet$ interferon
\end{abstract}

\section{Introduction}

The anemia of chronic disease is one of the most common hematologic disorders in clinical medicine (1). Among the inflammatory cytokines which have been proposed as mediators of this syndrome is tumor necrosis factor (TNF) $)^{1}(2,3)$. To understand the mechanism better by which TNF exerts its inhibitory effect on erythropoiesis, we studied its effect on in vitro colony formation by highly purified CFU-erythroid (E) generated from peripheral blood erythroid burst-forming units $(4,5)$. We found that the inhibitory effect of TNF was indirect and mediated by a soluble factor released from marrow acces-

Address reprint requests to Robert T. Means, Jr., M.D., Hematology/ Oncology Section (111D), Veterans Affairs Medical Center, 3200 Vine Street, Cincinnati, OH 45220.

Received for publication 11 February 1992 and in revised form 21 September 1992.

1. Abbreviations used in this paper: $\mathrm{CM}$, conditioned medium; $\mathrm{E}$, erythroid; IMDM, Iscove's modified Dulbecco's medium; LDMN, light density mononuclear cells; rTNF, recombinant TNF; TNF, tumor necrosis factor; TNFCM, TNF-stimulated CM.

The Journal of Clinical Investigation, Inc.

Volume 91, February 1993, 416-419 sory cells (6). These accessory cells resided in the marrow fraction precipitated by soybean agglutinin but were neither T lymphocytes nor monocytes.

We have continued our investigations into the inhibitory effect of TNF on CFU-E colony formation, and now report that this inhibitory effect requires the presence of human $\beta \mathrm{IFN}$, and that $\beta$ IFN itself exerts a direct inhibitory effect on CFU-E colony formation.

\section{Methods}

Blood and bone marrow were obtained from normal volunteers after informed consent. These studies were approved by the Vanderbilt University and Nashville Department of Veterans Affairs Medical Center Institutional Review Boards.

Recombinant human TNF $\alpha$ ( $r T N F)$. rTNF (bioactivity $24 \times 10^{6}$ $\mathrm{U} / \mathrm{mg}$ protein) was a generous gift from Dr. Abla Creasey, Cetus Corp., Emeryville, CA.

Human $\beta I F N$. $\beta$ IFN (sp act $1.0 \times 10^{5} \mathrm{U} / \mathrm{mg}$ protein) was purchased from Lee Biomolecular Sciences, San Diego, CA.

Neutralizing antibodies. Specific neutralizing antibodies to human $\gamma$ IFN, TNF, and IL-1 were purchased from Genzyme Corp., Boston MA. Neutralizing antibody specific for human $\beta$ IFN was purchased from Lee Biomolecular Sciences.

Purification of highly purified human CFU-E from peripheral blood. The method has been reported in detail by Sawada et al. $(4,5)$. Briefly, $400 \mathrm{ml}$ of heparinized blood from normal donors was separated over Ficoll-Hypaque ( $1.077 \mathrm{~g} / \mathrm{ml}$; Pharmacia Fine Chemicals, Picataway, NJ; Winthrop-Breon Laboratories, New York, NY) at 400 $g$ for $25 \mathrm{~min}$ at $24^{\circ} \mathrm{C}$. The light density mononuclear cells were collected in alpha MEM (Sigma Chemical Co., St. Louis, MO.), washed, and resuspended in Iscove's modified Dulbecco's medium (IMDM; Sigma Chemical Co. ). T cells were depleted by sheep erythrocyte rosetting (4). Adherent cells were then depleted by overnight incubation in $75 \mathrm{~cm}^{2}$ polystyrene tissue culture flasks in IMDM with 20\% FCS ( Hyclone Laboratories, Logan, UT) and $4 \%$ giant cell tumor conditioned medium (CM; Gibco Laboratories, Grand Island, NY) at $37^{\circ} \mathrm{C}$ in a $5 \%$ $\mathrm{CO}_{2}$ atmosphere.

After overnight incubation, the nonadherent cells were collected in $37^{\circ} \mathrm{C}$ MEM and underwent negative panning with $\mathrm{CD} 11 \mathrm{~b} / \mathrm{OKM}{ }^{*} 1$, CD2/OKT*11 (Ortho Diagnostic Systems, Raritan, NJ), CD45/ My11, and CD16/My23 as previously described (4), to remove colony-forming units granulocyte-macrophage, neutrophils, monocytes, lymphocytes, and natural killer cells. The remaining cells (typically $0.34 \%$ erythroid burst-forming units [4]) were then cultured at a concentration of $3 \times 10^{5} / \mathrm{ml}$ in $0.9 \%$ methylcellulose (Fisher Scientific Co., Fairlawn, NJ) with $30 \%$ FCS, $1 \%$ deionized HSA (American Red Cross Blood Services, Washington, DC), $10^{-4}$ M 2-mercaptoethanol (Eastman Kodak Co., Rochester, NY), penicillin $500 \mathrm{U} / \mathrm{ml}$, streptomycin $40 \mu \mathrm{g} / \mathrm{ml}$, recombinant human insulin $10 \mathrm{U} / \mathrm{ml}$ (Eli Lilly Co., Indianapolis, IN), recombinant human IL-3 $50 \mathrm{U} / \mathrm{ml}$ (Genetics Institute, Cambridge, MA), and recombinant human erythropoietin (Amgen Biologicals, Thousand Oaks, CA) $2 \mathrm{U} / \mathrm{ml}$, in 1-ml aliquots distributed into 12-well tissue culture plates (Limbro; Flow Laboratories, Inc., McLean, VA.) at $37^{\circ} \mathrm{C}$ in a high humidity $5 \% \mathrm{CO}_{2} / 95 \%$ air incubator. 
After $7 \mathrm{~d}$, the cells were collected in MEM. Debris and residual contaminating cells were then separated from highly purified CFU-E by centrifugation through 10\% BSA (Armour Pharmaceutical Co., Kankakee, IL), followed by centrifugation over Ficoll-Hypaque, and adherence in plastic flasks with $20 \% \mathrm{FCS}$ for $1 \mathrm{~h}$ at $37^{\circ} \mathrm{C}$. This process reproducibly yields a $94 \%$ viable population of day 8 peripheral blood cells, $30-90 \%$ of which are CFU-E $(4,5)$. The remaining $10-70 \%$ of cells are polymorphonuclear and basophilic leukocytes.

Marrow cell preparation. $6 \mathrm{ml}$ of bone marrow was aspirated from the posterior iliac crest and collected in an equal volume of IMDM containing $5 \mathrm{U}$ sodium heparin $/ \mathrm{ml}$. Marrow cells were then enriched for light density mononuclear cells (LDMN cells) by separation over Ficoll-Hypaque. In some experiments, marrow cells were depleted of T lymphocytes and adherent cells as described for peripheral blood, above.

Preparation of conditioned medium. CM was prepared from LDMN marrow cells suspended in IMDM with $30 \%$ FCS at a concentration of $1 \times 10^{7}$ cells $/ \mathrm{ml}$ and incubated at $37^{\circ} \mathrm{C}$ for $48 \mathrm{~h}$ in plastic tissue culture flasks with rTNF $10^{-10} \mathrm{M}$ ( TNFCM), as described previously (6). The cell suspension was collected and centrifuged at $400 \mathrm{~g}$ for $5 \mathrm{~min}$ to remove the cells. The cell-free supernatant was collected and stored at $-20^{\circ} \mathrm{C}$

Culture of CFU-E in plasma clots. Peripheral blood or marrow CFU-E were cultured at concentrations of $10^{3}$ peripheral blood day 8 cells (highly purified CFU-E) $/ \mathrm{ml}$ or $0.5-2.0 \times 10^{5}$ marrow cells $/ \mathrm{ml}$ with IMDM, $15 \%$ FCS, $15 \%$ pooled human AB serum, $0.25 \%$ HSA or BSA, recombinant erythropoietin $1 \mathrm{U} / \mathrm{ml}$, penicillin, streptomycin, epsilon aminocaproic acid $1.5 \mathrm{mM}$, fibrinogen $1.3 \mathrm{mg} / \mathrm{ml}$ (Fibrinogen Kabi, grade L; Kabi Diagnostica, Stockholm, Sweden) and thrombin $0.2 \mathrm{U} / \mathrm{ml}$ (Parke-Davis Pharmaceuticals, Morris Plains, NJ) with varying concentrations of hußIFN, TNFCM, and / or neutralizing antibodies to cytokines. In neutralizing antibody experiments, cells and culture medium were incubated with the antibody at $4^{\circ} \mathrm{C}$ for $1 \mathrm{~h}$ before the addition of rTNF or TNFCM. Cells were cultured for $7 \mathrm{~d}$ at $37^{\circ} \mathrm{C}$ in $5 \%$ $\mathrm{CO}_{2} / 95 \%$ air and then fixed and stained with benzidine-hematoxylin as described by McLeod et al. (7). Human CFU-E were defined as colonies of 8-49 hemoglobinized cells (8).

Each point was studied with three to six replicates, and results were normalized to the growth of control plasma clots (cultured without rTNF or TNFCM) so that results of different experiments might be compared. Statistical comparison was by $t$ test. Linear regression analysis was performed using a computer statistics program (Systat, Inc., Evanston, IL).

Assay for $\beta I F N$. CM was assayed for the presence of hu $\beta$ IFN using a commercially available ELISA kit purchased from Toray-Fuji Bionics, Inc., Tokyo, Japan.

\section{Results}

We previously reported that rTNF inhibited CFU-E colony formation by unpurified LDMN marrow cells (6). To identify the mediator of this inhibitory effect, LDMN marrow cells were cultured in plasma clots with rTNF $10^{-10} \mathrm{M}$ and with neutralizing antibodies to various human cytokines (Table I). The inhibitory effect of rTNF on CFU-E colony formation was completely ablated by neutralizing antibody to human $\beta$ IFN, but not by antibody to human $\gamma$ IFN or IL-1.

Although highly purified CFU-E colony formation is not inhibited by rTNF, TNFCM does have an inhibitory effect on these cells (6). To confirm the role of $\beta$ IFN in the inhibitory effect of TNF, highly purified CFU-E (mean purity $28.3 \%$ ) were cultured with TNFCM in the presence or absence of neutralizing antibody to human $\beta$ IFN (Table II). Anti- $\beta$ IFN completely reverses the inhibitory effect of TNFCM.

While rTNF does not exert a direct inhibitory effect on
Table I. Effect of Neutralizing Antibodies on Inhibition of Marrow CFU-E Colony Formation by Recombinant Human Tumor Necrosis Factor

\begin{tabular}{lc}
\hline & $\begin{array}{c}\text { CFU-E Colony } \\
\text { formation } \\
\text { (percent control) }\end{array}$ \\
\hline Medium only & $100.0 \pm 5.8$ \\
rTNF $10^{-10} \mathrm{M}$ & $59.8 \pm 5.9^{*}$ \\
rTNF $10^{-10} \mathrm{M}+$ anti- $\beta$ IFN $500 \mathrm{U} / \mathrm{ml}$ & $93.5 \pm 4.5$ \\
rTNF $10^{-10} \mathrm{M}+$ anti- $\gamma$ IFN $500 \mathrm{U} / \mathrm{ml}$ & $54.5 \pm 4.2^{*}$ \\
rTNF $10^{-10} \mathrm{M}+$ anti-IL-1 $200 \mathrm{U} / \mathrm{ml}$ & $55.1 \pm 4.9^{*}$ \\
anti- $\beta$ IFN $500 \mathrm{U} / \mathrm{ml}$ & $90.3 \pm 4.1$ \\
anti- $\gamma$ IFN $500 \mathrm{U} / \mathrm{ml}$ & $88.9 \pm 4.1$ \\
anti-IL-1 $200 \mathrm{U} / \mathrm{ml}$ & $92.6 \pm 2.9$ \\
\hline
\end{tabular}

Data from three experiments, using LDMN cells containing $0.49 \pm 0.10 \%$ CFU-E (98 \pm 20 CFU-E/plasma clot), are combined. Results are expressed as mean \pm SE. ${ }^{*} P<0.03$.

colony formation by highly purified CFU-E, it is possible that rTNF may sensitize these cells to the effect of a direct inhibitor or inhibitors present in TNFCM. To address this possibility, highly purified CFU-E (mean purity $21.7 \%$ ) were cultured with TNFCM in the presence of neutralizing antibodies to human TNF. The inhibitory effect of TNFCM was not altered by anti-TNF ( Table III), indicating that the only role of rTNF in inhibition of CFU-E colony formation is to stimulate the release of a direct inhibitor.

If $\beta$ IFN is a mediator of the inhibitory effect of TNF on CFU-E colony formation, the addition of this cytokine to plasma clots containing highly purified CFU-E should lead to decreased colony formation. $\beta$ IFN inhibited colony formation by highly purified CFU-E (mean purity $21.0 \%$ ) in a dose-dependent fashion (Fig. 1).

To determine whether the inhibitory effect of $\beta$ IFN is a direct effect, limiting dilution analysis was performed on highly purified CFU-E exposed to $\beta$ IFN at a concentration of 1,000 $\mathrm{U} / \mathrm{ml}(5,9)$. If the effect of $\beta$ IFN was indirect, the graph of the limiting dilution plot would be biphasic, with the line originally pointing away from the origin and then turning toward the origin as the CFU-E are diluted out. The points shown in Fig. 2 fall on a straight line passing though the origin $\left(C_{\text {corr }}=-0.99\right)$, indicating that the inhibitory effect of $\beta$ IFN is the result of direct action on the CFU-E.

$\beta$ IFN also inhibits colony formation by CFU-E from unpurified marrow cells (Fig. 3). As shown in the Fig. 3, T lymphocyte or adherent cell depletion of LDMN marrow cells does not significantly alter the degree of inhibition $(P>0.05$ by linear regression analysis).

If $\beta$ IFN were the sole factor involved in the inhibitory effect of rTNF on CFU-E colony formation, then the concentration of $\beta$ IFN present in TNFCM could be estimated by comparing the inhibitory effect produced by TNFCM to the $\beta$ IFN dose response curve for highly purified CFU-E. These values indicate that $10 \%$ TNFCM decreases CFU-E colony formation to $\sim 52 \%$ of control ( Tables II and III), and a comparable effect would require $\sim 10-100 \mathrm{U} / \mathrm{ml} \mathrm{hu} \beta$ IFN (Fig. 1). Thus, if $\beta$ IFN is the sole mediator of the inhibitory effect of TNF, then undiluted TNFCM should contain $100-1,000 \mathrm{U} / \mathrm{ml} \beta \mathrm{IFN}$. 
Table II. Effect of Neutralizing Antibodies on Inhibition of CFU-E Colony Formation by TNFCM

\begin{tabular}{lc}
\hline & $\begin{array}{c}\text { Highly purified } \\
\text { CFU-E colony } \\
\text { formation } \\
\text { (percent control) }\end{array}$ \\
\hline Medium only & $100.0 \pm 7.3$ \\
$+10 \%$ TNFCM & $53.7 \pm 5.7^{*}$ \\
$+10 \%$ TNFCM + anti- $\beta$ IFN 250 U & $96.0 \pm 6.1$ \\
anti- $\beta$ IFN 250 U & $93.0 \pm 5.8$ \\
\hline
\end{tabular}

Data from three experiments, with CFU-E purity $28.3 \pm 5.6(56 \pm 11$ CFU-E/plasma clot), are combined. Results are expressed as mean \pm SE. ${ }^{*} P<0.05$

However, an ELISA specific for hu $\beta$ IFN (Toray-Fuji Bionics) indicated that $\beta$ IFN concentration was $<2.5 \mathrm{U} / \mathrm{ml}$. Therefore, hu $\beta$ IFN, while required for the inhibitory effect of rTNF on CFU-E, is not the sole responsible factor, but acts in synergy with some other, as yet unidentified, factor or factors.

\section{Discussion}

In our previous study of the inhibitory effect of rTNF on CFUE colony formation, we demonstrated that unpurified LDMN marrow cell colony formation was inhibited by rTNF, but no inhibitory effect was seen with highly purified CFU-E (6). We further demonstrated that this inhibition was mediated by a soluble factor or factors released from the soybean agglutininagglutinated fraction of marrow in response to rTNF (6). The present report demonstrates that $\beta I F N$ is one of the factors required for this effect.

It has previously been shown that $\beta$ IFN inhibits colony formation by marrow BFU-E (10), but no further work has been reported on the mechanism by which this inhibition occurs: whether it acts through other cytokines released from accessory cells, or by a direct effect on erythroid progenitor cells. In this report, we demonstrate that $\beta$ IFN inhibits colony formation by highly purified human CFU-E, that depletion of accessory cells does not alter $\beta$ IFN's inhibitory effect on marrow CFU-E col-

Table III. Effect of Neutralizing Antibodies to Human TNF on Inhibition of CFU-E Colony Formation by TNFCM

\begin{tabular}{lc}
\hline & $\begin{array}{c}\text { Highly purified } \\
\text { CFU-E colony } \\
\text { formation } \\
\text { (percent control) }\end{array}$ \\
\hline Medium only & $100.0 \pm 4.5$ \\
$+10 \%$ TNFCM & $50.4 \pm 4.2^{*}$ \\
$+10 \%$ TNFCM + anti-TNF $10^{5} \mathrm{U}$ & $52.2 \pm 4.5^{*}$ \\
anti-TNF $10^{5} \mathrm{U}$ & $95.1 \pm 4.3$ \\
\hline
\end{tabular}

Data from three experiments, with CFU-E purity $21.7 \pm 4.0(43 \pm 8$ CFU-E/plasma clot), are combined. Results are expressed as mean \pm SE. ${ }^{*} P<0.01$ compared to medium only or medium + anti TNF.

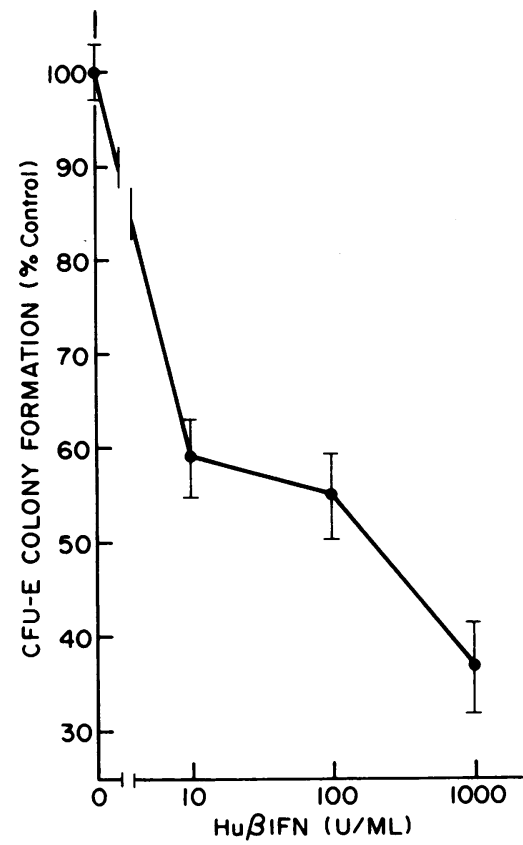

Figure 1. Effect of mation by highly purified CFU-E. Data from three experiments, with CFU-E purity $21.0 \pm 5.8 \%(42 \pm 11$ CFU-E/plasma clot), are shown. Results are expressed as mean $\pm \mathrm{SE}$ hu $\beta$ IFN on colony for-

ony formation, and that $\beta$ IFN inhibits CFU-E colony formation directly, as shown by limiting dilution analysis.

We believe that this report also provides the first evidence suggesting a role for $\beta$ IFN in the anemia associated with chronic inflammatory disease. As mentioned above, TNF is a proposed mediator of the anemia of chronic disease $(2,3,11)$. This has been shown by the development of a similar anemia in mice exposed to TNF (3) and in patients treated with TNF (12), as well as the demonstration of elevated serum TNF levels in patients with infectious and neoplastic diseases (13). However, the mechanism of this effect has been unknown. The studies reported here demonstrate that, for human CFU-E in vitro, the inhibitory effect of TNF requires $\beta$ IFN.

Such an inhibitory role would be consistent with the reported effects of $\beta$ IFN on cellular growth and differentiation. $\beta$ IFN appears to inhibit growth stimulatory signaling pathways directly (14), and appears to be involved in the natural suppression of immune proliferation in response to stimuli (15).

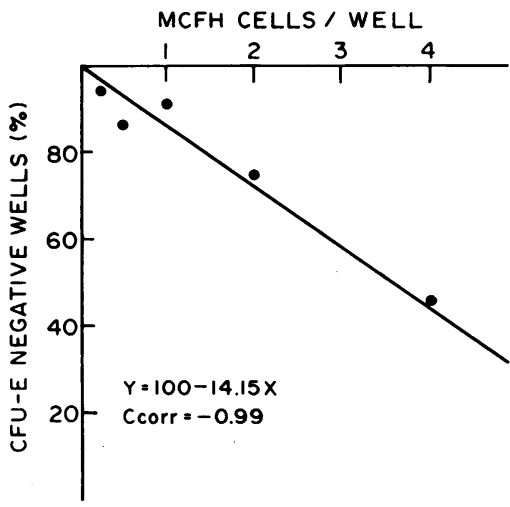

Figure 2. Limiting dilution analysis of CFU-E growth in the presence of $\beta$ IFN $1,000 \mathrm{U} / \mathrm{ml}$. Highly purified CFU-E were suspended in medium at concentrations of $5,10,20,40$, and 80 day 8 , postmethylcellulose $(M C F H)$ cells $/ \mathrm{ml}$ and plated as $50-\mu 1$ plasma clots in a 96-well plate. Each point represents the result of 19-24 wells. CFU-E purity was $44.5 \%$ ( 89 CFU-E/

plasma clot). $\beta$ IFN $1,000 \mathrm{U} / \mathrm{ml}$ inhibited colony formation to $52.5 \%$ of control (47 CFU-E/plasma clot). 


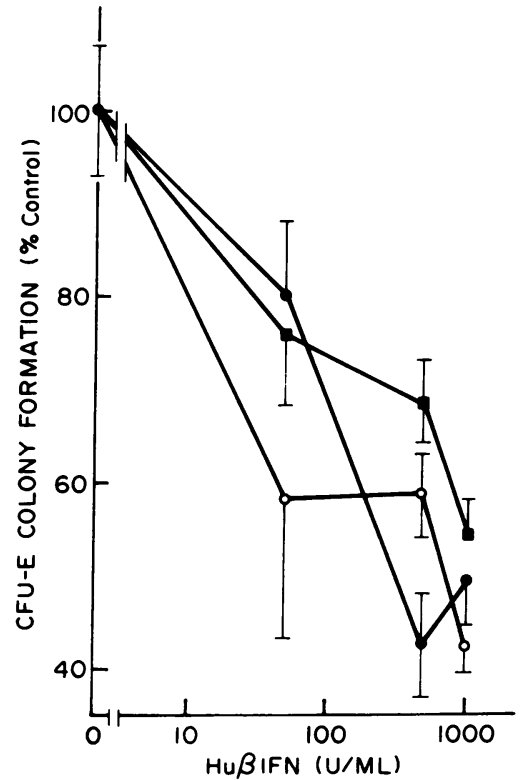

Figure 3. Effect of $\beta$ IFN on CFU-E colony formation by marrow cells. Data from three experiments are shown, with LDMN marrow cells $(\bullet ; 0.24 \pm 0.06 \%$ CFU-E; $48 \pm 12$ CFU-E/plasma clot), adherent cell depleted LDMN cells ( $O$; $0.28 \pm 0.06 \%$ CFU-E; $56 \pm 12$ CFU-E/plasma clot), and $T$ lymphocyte-depleted LDMN marrow cells $(\square$; $0.46 \pm 0.11 \%$ CFU-E; $92 \pm 22$ CFU-E/plasma clot). Results are expressed as mean \pm SE.

In addition, human erythroid progenitors appear to be much more sensitive to inhibition by $\beta$ IFN than are myeloid progenitors (10), suggesting a preferential effect on erythropoiesis. The studies presented here indicate that $\beta$ IFN in addition to suppressing the growth of non-hematopoietic cell lines (14) also directly suppresses the further development of an end-stage erythroid progenitor cell that requires only two cytokines (erythropoietin and insulin-like growth factor I [5]) for terminal differentiation.

The soybean agglutinin-agglutinated fraction of marrow includes preadipocytes, fibroblasts, and endothelial cells (16). Shah and colleagues cultured these cells from human marrow in long-term liquid cultures and derived clonal cell lines of fibroblast-like cells (17). Superinduction of these cells with poly I-poly $\mathrm{C}$ led to the production of large quantities of $\beta \mathrm{IFN}$ $\left(10^{3} \mathrm{U} / \mathrm{ml}\right)(17)$. Castro-Malaspina et al. also studied marrow stromal cells in liquid culture and found that these cells gave rise to fibroblast colonies (18). TNF has been shown to induce $\beta$ IFN in fibroblasts $(19,20)$, suggesting that these are the marrow cells ultimately responsible for the inhibitory effect of TNF on erythropoiesis.

Our previous report did not rule out the possibility that rTNF, while not the direct mediator of CFU-E inhibition, might sensitize these cells to a direct inhibitor (6). The antibody studies presented above demonstrate that this is not the case (Table III). However, the investigations reported here strongly indicate that rTNF induces some other factor (other than those tested in this study) which acts in either a synergistic or a cooperative manner with $\beta$ IFN.

In conclusion, we have demonstrated that inhibition of human CFU-E colony formation in vitro by TNF requires $\beta$ IFN and that $\beta$ IFN exerts a direct inhibitory effect on human CFUE. Insufficient quantities of $\beta$ IFN are present to be the sole mediator of this inhibition, indicating that $\beta$ IFN acts in cooperation with other factors, as yet unidentified, to inhibit CFU-E colony formation. The source of $\beta$ IFN is not directly identified, but resides in a marrow stromal cell fraction that has been previously demonstrated to produce $\beta$ IFN in response to induction $(17,19,20)$.

\section{Acknowledgments}

The authors are grateful for the generous gifts of recombinant human IL-3 from Dr. Steven Clark, Genetics Institute, Cambridge, MA, of rTNF from Dr. Abla Creasey, Cetus Corp., Emeryville, CA, and for the expert technical assistance of Mrs. Millie Clancey in carrying out these studies.

This work was supported by Veterans Health Administration Merit Review grants (R. T. Means and S. B. Krantz), by grants DK-15555 and 2 T32-DK07186 from the National Institutes of Health (S. B. Krantz), and by the Joe C. Davis Hematology Research Fund.

\section{References} 80 .

1. Lee, G. R. 1983. The anemia of chronic disease. Semin. Hematol. 20:61-

2. Roodman, G. D., A. Bird, D. Hatzler, and W. Montgomery. 1987. Tumor necrosis factor alpha and hematopoietic progenitors: effect of tumor necrosis factor on the growth of erythroid progenitors CFU-E and BFU-E and the hematopoietic cell lines k562, HL60, and HEL cells. Exp. Hematol. (NY). 15:928-935.

3. Johnson, R. A., T. A. Waddelow, J. Caro, A. Oliff, and G. D. Roodman. 1989. Chronic exposure to tumor necrosis factor in vivo preferentially inhibits erythropoiesis in nude mice. Blood. 74:130-138.

4. Sawada, K., S. B. Krantz, J. S. Kans, E. N. Dessypris, S. Sawyer, A. D. Glick, and C. I. Civin. 1987. Purification of human erythroid colony-forming units and demonstration of specific binding of erythropoietin. J. Clin. Invest. 80:357-366.

5. Sawada, K., S. B. Krantz, E. N. Dessypris, S. T. Koury, and S. T. Sawyer 1989. Human colony-forming units-erythroid do not require accessory cells but do require direct interaction with insulin-like growth factor-I and/or insulin for erythroid development. J. Clin. Invest. 83:1701-1709.

6. Means, R. T., E. N. Dessypris, and S. B. Krantz. 1990. Inhibition of human colony-forming units-erythroid by tumor necrosis factor requires accessory cells. J. Clin. Invest. 86:538-541.

7. McLeod, D. L., M. M. Shreeve, and A. A. Axelrad. 1974. Improved plasma culture system for production of erythrocytic colonies in vitro: quantitative assay method for CFU-E. Blood. 44:517-534.

8. Eaves, A. C., and C. J. Eaves. 1984. Erythropoiesis in culture. Clin. Haematol. 13:371-391.

9. Lef kovits, I., and H. Waldmann. 1979. Limiting Dilution Analysis of Cells in the Immune System. Cambridge University Press, Cambridge. 262 pp.

10. Broxmeyer, H. E., L. Lu, E. Platzer, C. Feit, L. Juliano, and B. Y. Rubin. 1983. Comparatine analysis of the influences of human gamma, alpha, and beta interferons on human multipotential (CFU-GEMM), erythroid (BFU-E), and granulocyte-macrophage (CFU-GM) progenitor cells. J. Immunol. 131:13001305.

11. Roodman, G. D. 1987. Mechanisms of erythroid suppression in the anemia of chronic disease. Blood Cells (NY). 13:171-184.

12. Blick, M., S. A. Sherwin, M. Rosenblum, and J. Gutterman. 1987. Phase I study of recombinant tumor necrosis factor in cancer patients. Cancer Res. 47:2986-2989.

13. Teppo, A.-M., and C. P. J. Maury. 1987. Radioimmunoassay of tumor necrosis factor in serum. Clin. Chem. 33:2024-2027.

14. Mundschau, L. J., and D. V. Faller. 1991. BALB/c-3T3 fibroblasts resistant to growth inhibition by beta interferon exhibit aberrant platelet-derived growth factor, epidermal growth factor, and fibroblast growth factor signal transduction. Mol. Cell Biol. 11:3148-3154.

15. Cleveland, M. G., R. G. Lane, and G. R. Klimpel. 1988. Spontaneous IFN- $\beta$ production: a common feature of natural suppressor systems. J. Immunol. 141:2043-2049.

16. Ebell, W., H. Castro-Malaspina, M. A. S. Moore, and R. J. O'Reilly. 1985. Depletion of stromal elements in human marrow grafts separated by soybean agglutinin. Blood. 65:1105-1111.

17. Shah, G., T. M. Dexter, and M. Lanotte. 1983. Interferon production by human marrow stromal cells. Br. J. Haematol. 54:365-372.

18. Castro-Malaspina, H., R. E. Gay, N. Kapoor, P. Meyers, D. Chiarieri, S. McKenzie, H. E. Broxmeyer, and M. A. S. Moore. 1980. Characterization of human bone marrow fibroblast colony-forming cells (CFU-F) and their progeny. Blood. 56:289-301.

19. Reis, L. F. L., J. Le, T. Hirano, T. Kishimoto, and J. Vilcek. 1988. Antiviral action of tumor necrosis factor in human fibroblasts is not mediated by $B$ cell stimulatory factor $2 /$ IFB- $\beta_{2}$, and is inhibited by specific antibodies to IFN- $\beta$. J. Immunol. 140:1566-1570.

20. Reis, L. F. L., T. H. Lee, and J. Vilcek. 1989. Tumor necrosis factor acts synergistically with autocrine interferon- $\beta$ and increases interferon- $\beta$ mRNA levels in human fibroblasts. J. Biol. Chem. 264:16351-16354. 